\title{
Kultura misji
}

W czołówce otwierającej drugi sezon Star Treka kapitan James K. Kirk tak przedstawiał misję statku kosmicznego „Enterprise”: „Zbadać nowe obce światy, odkrywać nowe życie i nowe cywilizacje. Odważnie docierać tam, gdzie nikt wcześniej nie dotarł". Nadając prezentowanemu numerowi tytuł Kultura misji, chcemy przyjrzeć się rozmaitym projektom kulturowym, które były i są podejmowane pod hasłem „misji”. Przyglądając się różnym typom misji (cywilizacyjnym, religijnym, naukowym, politycznym, kosmicznym czy ekologicznym), pytamy o to, co jest dla nich wspólne. W naszym przekonaniu tym, co łączy tak różne przedsięwzięcia, jest ich związek z wartościami, dzięki czemu stanowią one interesujący przedmiot badań kulturoznawczych.

Ten aksjotyczny aspekt widoczny jest już w definicji słownikowej. Według Stownika jezzkka polskiego „misja” to „odpowiedzialne zadanie do spełnienia, ważne zlecenie do wykonania; posłannictwo" . Misje wymagają zaangażowania, pociągają za sobą kwestię odpowiedzialności, podejmowane są w imię różnych wartości. Towarzyszyć im może rozpoznanie braku czy niedostatku, wręcz aksjotycznej próżni w rzeczywistości. Taki stan rzeczy należy zmienić, stąd potrzeba działania w imię wyższego „,dobra”. Charakterystyczną cechą misji jest realizacja wartości (poznawczych, religijnych, etycznych i innych), a ich celem - przekształcenie istniejącego status quo. Misje są świadectwem kulturowej różnorodności, przez co mogą prowadzić do aksjotycznych konfliktów, zderzenia niewspółmiernych skal i układów wartości (jak w wypadku misji kolonizacyjnych). Jakkolwiek towarzyszą im szczytne cele, mają one swoją ciemną stronę związaną z podbojem, wyzyskiem czy eksploatacją środowiska.

Teksty zgromadzone w tym numerze dotyczą różnego rodzaju misji, także tych realizowanych przez ważne instytucje, takie jak muzea (o funkcjach muzeów w Chinach pisze Michał Witek) czy uniwersytety (przypadek reformy uniwersyteckiej w Chile analizuje Magdalena Barbaruk). Każda z nich odsyła do pewnego horyzontu wartości. Niektóre z prezentowanych artykułów omawiają misje epoki kolonialnej - Anna Maria Busse Berger analizuje w tym kontekście działalność Brunona Gutmanna i Franza Ferdinanda Rietzscha, niemieckich misjonarzy w Afryce, którzy podjęli próbę przekładu na lokalne systemy tonalne

1 Stownik języka polskiego, t. 2, Warszawa 1995, s. 176. 
hymnów kościelnych. W tym kontekście interesującym przypadkiem jest również postać księdza Władysława Michała Zaleskiego — polskiego duchownego, który odbywał misję w Indiach Wschodnich. Jego kolekcja ilustracji roślin tropikalnych oraz fotografii wykonanych w Indiach, zebranych przez Krystynę Jędrzejewską-Szmek i Łukasza Gniadka w albumie Tropicale, jest ciekawym przykładem tego, jak działalność naukowa łączy się z kolonializmem. Renata Tańczuk omawia z kolei Watykańską Wystawę Misyjną z 1925 roku, która ujawnia powiązania misji ewangelizacyjnych $\mathrm{z}$ badaniami etnograficznymi. Jednym $\mathrm{z}$ bohaterów tego tekstu jest ojciec Wilhelm Schmidt. Jego artykuł Nauki o ludach i językach a katoliccy misjonarze z 1906 roku, fundujący czasopismo naukowe „Anthropos”, publikujemy w dziale „Archiwum”. Schmidt zachęcał misjonarzy do prowadzenia działalności badawczej, a jego tekst stanowi ciekawe świadectwo ówczesnych aspiracji etnologii. Założony przez Schmidta w 1932 roku Instytut Anthropos stał się ważną placówką badawczą i edukacyjną. Wagę powołanego przez niego czasopisma doceniało wielu badaczy, między innymi angielski antropolog Raymond Firth oraz Robert Lowie. Ten ostatni twierdził, że „Antropologia wiele zawdzięcza Schmidtowi, założycielowi pisma »Anthropos«, nieustępującemu żadnymi innemu w tej dziedzinie". Z kolei antropolog-misjonarz Edwin William Smith zauważył, że: „Ze względu na wkład misjonarzy w osiągnięcia antropologii, jak również ze względu na użyteczność tej nauki w codziennej pracy misjonarza można niemal uważać antropologię społeczną za naukę misjonarską" ${ }^{2}$. Działalność ewangelizacyjna, badawcza, kolekcjonerska czy ekspozycyjna misjonarzy i misjonarek prowadziły do powstania powiązań, często trudnych do rozwiązania, między religią, nauką, ekonomią, polityką.

W dziale archiwalnym publikujemy także dwa fragmenty z Archipelagu Malajskiego Alfreda R. Wallace'a (1823-1913), naturalisty trudniącego się na początku swej kariery zbieraniem okazów przyrodniczych, który zdobył uznanie takich osobistości jak Charles Darwin czy Charles Lyell, a jego książka stała się jedną z najważniejszych inspiracji dla kolejnych pokoleń badaczy, podróżników i pisarzy (Arkady Fiedler, Joseph Conrad), rozpalając wyobraźnię szerokiej rzeszy czytelników ${ }^{3}$. Jego opis holenderskiej kolonii na Celebesie, będący dość zaskakującym peanem na cześć holenderskich rządów kolonialnych, już wówczas

2 Przywołane tu wypowiedzi zamieścił Louis J. Luzbetak w swojej książce-podręczniku Kościól a kultury. Antropologia stosowana na użytek misjonarzy z 1963 roku (przeł. I. Józeficzowa, Warszawa 1972).

3 Wydany 9 marca 1869 roku Archipelag Malajski doczekał się licznych wydań, reprintów, dodruków i przekładów na języki obce, a jego popularność wydaje się nie gasnąć. Niestety jak dotąd nie pojawił się żaden całościowy przekład na język polski. Fragmenty były publikowane w czasopiśmie „Wędrowiec” w 1874 roku pod tytułem Archipelag Malajski. Ustęp z podróży Alfreda Russel Wallace („Wędrowiec” 9, 1874, nr 233, s. 385; nr 234, s. [401]; 10, 1874, nr 235, s. 11; nr 236, s. 17; nr 237, s. 33 ; nr 238, s. 49 ; nr 239, s. 71 ; nr 240, s. 87 ; nr 241, s. 99; nr 242, s. 125 ; nr 243, s. 138; nr 245, s. 155). 
ostro krytykowanych, jest interesującym przykładem pojmowania misji cywilizacyjnej i roli, jaką odgrywali w niej misjonarze. Drugi z wybranych fragmentów pochodzi z rozdziału poświęconego polowaniu na borneańskie orangutany. Jak wyznaje Wallace: „Głównym celem mojej podróży było pozyskanie okazów historii naturalnej" 4 . Podczas swej wyprawy zgromadził on 125660 okazów. Relacja ta jest z dzisiejszej perspektywy porażającym świadectwem pasji pozyskiwania eksponatów do kolekcji muzealnych. Współczesnego czytelnika przerażają sceny zadawanych zwierzętom cierpień i dokonywanych na nich mordów. W opublikowanym w 1869 roku na łamach bogato ilustrowanego tygodnika literackiego „Once a Week” artykule Historia naturalna Archipelagu Wschodniego, będącym streszczeniem fragmentu o orangutanach wraz z cytatami zaczerpniętymi z innych autorów, którzy wspominają o polowaniach na „Oranga” przed Wallacem, odnajdujemy następujący komentarz:

\begin{abstract}
Był to ostatni Mias, jakiego Pan Wallace ustrzelił, czyniąc go swą szesnastą ofiarą. Jako że dziewięć z nich zostało ustrzelonych pomiędzy 24 kwietnia a 27 czerwca, łowy muszą zostać uznane za zdecydowanie dobre. Podajemy te szczegóły udanych łowów w nadziei, że może skłonimy jakiegoś przedsiębiorczego rodaka, żeby na jeden sezon zaniechał podchodzenia jeleni i spróbował swych umiejętności u „biednych krewnych” na Borneo. Zastanie tam nie tylko serdeczne powitanie ze strony Dajaków, którzy uważają Miasa za swego naturalnego wroga, ale może też odnieść sukces, rozwiązując problem poruszony przez Pana Wallace'a, dotyczący przypuszczalnego istnienia borneańskiego Oranga tak wielkiego jak goryl ${ }^{5}$.
\end{abstract}

Z perspektywy czasu fragment ten jest przykładem działania kolonialnej „maszyny antropologicznej" wyznaczającej granicę między tym, co ludzkie i nie-ludzkie, na dwa sposoby. Z jednej strony chodzi o relacje między człowiekiem a zwierzęciem, z drugiej — między nami (Europejczykami) a Innymi (ze względu na płeć, rasę, tożsamość etniczną). Do tej problematyki odnosi się tekst Małgorzaty Dancewicz poświęcony twórczości kubańskiej artystki Coco Fusco, która w swych performansach eksploruje wspomniane granice. Ta ,antropologiczna różnica" wytwarzana jest również w filmach amerykańskich z lat dwudziestych i trzydziestych z nurtu filmu ekspedycyjnego i kina egzotycznej eksploracji (na przykład King Kong) analizowanych przez Roberta Zontka.

Jak pokazują publikowane w tym numerze teksty, w XX wieku kolonialne misje cywilizacyjne przenoszą się w kosmos. W tym sensie podbój kosmosu, o czym pisze Agnieszka Jelewska, może być traktowany jako przedłużenie projektów kolonialnych, a sam globus (i inne narzędzia służące do „projektowania”

${ }^{4}$ A.R. Wallace, The Malay Archipelago: The Land of the Orang-Utan, and the Bird of Paradise. A Narrative of Travel, with Studies of Man and Nature, London 1869, s. XIV; jeśli nie podano inaczej, przeł. K. Tańczuk.

5 The natural history of The Eastern Archipelago, „Once a Week” 1869, nr 103, s. 430-435, https://books.google.pl/books?id=Uu4jAQAAIAAJ\&pg=PA431\&dq=Sem\%C3\%A1bang\&hl=pl\&sa $=\mathrm{X} \& \mathrm{ved}=0$ ahUKEwiqnN235O3jAhUqpYsKHRcACw4Q6AEISjAE\# $\mathrm{v}=$ onepage $\& \mathrm{q}=\mathrm{Sem} \% \mathrm{C} 3 \% \mathrm{~A} 1$ bang\&f=false (dostęp: 24.08.2019).

Prace Kulturoznawcze 23, 2019, nr 2-3

(C) for this edition by CNS 
Ziemi) jako „medium praktyk kolonizacyjnych”. O tym, jak zmieniały się filmowe przedstawienia podróży na Księżyc i jaką rolę odegrały w amerykańskiej mitologii, traktuje tekst Dawida Junkego. Z kolei Dariusz Brzostek, analizując funkcje poznawcze powieści Stanisława Lema i Petera Wattsa, pokazuje, że strategie narracyjne używane w literaturze science fiction (nazywanej przez autora „antropologią spekulatywną") mają swe źródło w relacjach antropologów na temat spotkania z obcymi kulturami. Natomiast współcześnie pojęcie misji pojawia się w nowym, ekologicznym kontekście. Nie chodzi już o cywilizowanie obcych czy nawracanie Innych na „naszą” religię, lecz o ratowanie planety w obliczu zagrożeń związanych ze zmianami klimatycznymi. W tym kontekście Anna Nacher analizuje ruch permakultury, który określa mianem „misji bez misji”. Charakteryzuje się on odrzuceniem z góry narzuconych, dogmatycznych rozwiązań i wypracowaniu lokalnych praktyk w lokalnych ekosystemach. Ta ekologiczna perspektywa pozwala także inaczej spojrzeć na misje kolonizacyjne i dostrzec ich wymiar środowiskowy.

Jacek Małczyński

Renata Tańczuk 